\title{
Erratum to: 'Modified transesophageal echocardiography of the dissected thoracic aorta; a novel diagnostic approach'
}

Wouter W. Jansen Klomp ${ }^{1,2^{*}}$, Linda M. Peelen ${ }^{2,3}$, George J. Brandon Bravo Bruinsma ${ }^{4}$, Arnoud W. J. van't Hof ${ }^{1}$, Jan G. Grandjean ${ }^{5}$ and Arno P. Nierich ${ }^{6}$

\section{Erratum}

Unfortunately, the original version of this article [1] contained an error. The competing interests section was published with an error.

"WJK received financial support for an E-learning course and congress presentation from Medical2Market B.V. AN holds stock in Medical2Market B.V., Zwolle, the Netherlands."

should be:

"WJK received financial support for an E-learning course and congress presentation from Stroke2prevent B.V. and AN holds stock in Stroke2prevent B.V., Zwolle, the Netherlands."

\begin{abstract}
Author details
'Department of Cardiology, V2.2, ISALA, Zwolle, The Netherlands.

${ }^{2}$ Department of Clinical Epidemiology, Julius Center for Health Sciences and Primary Care, University Medical Center Utrecht, Utrecht, The Netherlands.

${ }^{3}$ Department of Anesthesiology, University Medical Center Utrecht, Utrecht, The Netherlands. ${ }^{4}$ Department of Cardiothoracic Surgery, ISALA, Zwolle, The Netherlands. ${ }^{5}$ MIRA Institute for Biomedical Technology and Technical Medicine, University of Twente, Enschede, The Netherlands. ${ }^{6}$ Department of (Thoracic) Anaesthesia and Intensive Care, ISALA, Zwolle, The Netherlands.
\end{abstract}

Received: 1 September 2016 Accepted: 1 September 2016

Published online: 08 September 2016

\section{Reference}

1. Jansen Klomp WW, Peelen LM, Brandon Bravo Bruinsma GJ, van't Hof AWJ, Grandjean JG, Nierich AP. Modified transesophageal echocardiography of the dissected thoracic aorta; a novel diagnostic approach. Cardiovasc Ultrasound. 2016;14:28.

\footnotetext{
* Correspondence: w.w.jansen.klomp@isala.nl

'Department of Cardiology, V2.2, ISALA, Zwolle, The Netherlands

${ }^{2}$ Department of Clinical Epidemiology, Julius Center for Health Sciences and Primary Care, University Medical Center Utrecht, Utrecht, The Netherlands Full list of author information is available at the end of the article
}

\footnotetext{
Submit your next manuscript to BioMed Central and we will help you at every step:

- We accept pre-submission inquiries

- Our selector tool helps you to find the most relevant journal

- We provide round the clock customer support

- Convenient online submission

- Thorough peer review

- Inclusion in PubMed and all major indexing services

- Maximum visibility for your research
}

Submit your manuscript at www.biomedcentral.com/submit 